University of New Hampshire

University of New Hampshire Scholars' Repository

1999

\title{
Ecological and population changes in fishing communities of the North Atlantic Arc
}

Lawrence C. Hamilton

University of New Hampshire, lawrence.hamilton@unh.edu

Richard L. Haedrich

Memorial University of Newfoundland

Follow this and additional works at: https://scholars.unh.edu/soc_facpub

Part of the Sociology Commons

\section{Recommended Citation}

Hamilton, L.C., Haedrich, R.L. Ecological and population changes in fishing communities of the North Atlantic Arc. (1999) Polar Research, 18 (2), pp. 383-388.

This Article is brought to you for free and open access by the Sociology at University of New Hampshire Scholars' Repository. It has been accepted for inclusion in Sociology Scholarship by an authorized administrator of University of New Hampshire Scholars' Repository. For more information, please contact Scholarly.Communication@unh.edu. 


\title{
Ecological and population changes in fishing communities of the North Atlantic Arc
}

\author{
Lawrence C. Hamilton \& Richard L. Haedrich
}

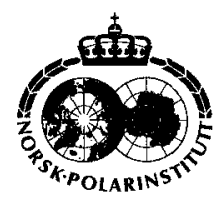

\begin{abstract}
In the decades since World War II, large-scale ecological changes have affected fishing communities across the northern Atlantic. Substantial declines hit their historically important resources. most notably the Atlantic cod. Such declines were often accompanied by increases in other, previously less exploited, species. Interactions between fishing pressure and environmental variation have driven ecological change. Ecological changes in turn reshaped the fisheries, contributing to altered demographic profiles of fisheries-dependent communities. Many places lost population, especially through out-migration of young adults. Broad social forces also contributed to these trends, but the timing and geographical details of population changes often correspond to specific fisheries/ecological events.
\end{abstract}

L. C. Hamilton, Sociology Dept., University of New Hampshire, Durham, NH 03824, USA; R. L. Haedrich, Biology Dept., Memorial University of Newfoundland, St. John's, Newfoundland AlC 5S7, Canada.

\section{Introduction}

The North Atlantic Arc refers to the coasts and islands across the northern rim of the Atlantic: from Norway through the Faroe Islands, Iceland and Greenland to Newfoundland. Historically, this was the path of Viking Age expansion, and the setting for the first known contacts between Old and New World cultures. Today, Atlantic Arc societies have in common a problematic dependence on fisheries, with limited economic alternatives in their sub-Arctic environments.

Computer projections of the future, as well as palaeoclimate reconstructions of the past, identify the northern Atlantic as a critical region for global climate change (e.g. Mayewski et al. 1994; Manabe 1995; Rahmstorf 1995; Weaver 1995). Its circulation, driven by both temperature and salinity, is sensitive to small changes in precipitation, temperature structure and/or winds (Broecker 1997). Shifts between very different climate regimes occurred during the Pleistocene on time scales of decades or less. The present northern climate regime - relatively warm, wet and calm - favours human life at high latitudes, whereas the Pleistocene alternative - cold, dry and windy - did not.

Regime shifts present a worst-case global change scenario, outside of historical experience. Less severe variations, however, have been observed in the 20th century. Such variations can interact with fishing to cause ecological change, forcing social adaptations among fisheries-dependent peoples. In this paper, we examine some demographic manifestations of the interlinked changes taking place among fish and fishing communities.

\section{Environmental and fisheries effects}

The collapse of Newfoundland's northern cod fishery in 1991-92 coincided with unusual ice conditions and a broadening of the cold intermediate layer of the Labrador Current. This coincidence fueled speculation that cold water had killed or driven out the cod (deYoung \& Rose 1993). In some quarters the speculation was hopeful: perhaps nature, and not overfishing, was to blame for this ecological disaster. But on finer scales the cold water distribution appeared patchy, and even at its greatest extent, there remained vast areas still suitable for cod (Haedrich et al. 1997). Careful analysts reached the conclusion that 
overfishing alone best explains the northern cod collapse (Hutchings \& Myers 1994, 1995; Sinclair \& Murawski 1997). Cold water could have facilitated overfishing, however, by concentrating the cod and making them easier to catch (Martin 1995). Writing prior to the Newfoundland collapse, Jakobsson (1992: 313-314) observed:

"As the time series for stock fluctuations and environmental data have lengthened it has become more and more evident that major variability in fisheries usually has at least two different sources, i.e. anthropogenic sources and environmental sources. A high exploitation rate places stress on the marine populations, rendering them vulnerable to changing environmental effects."

Vilhjálmsson (1997) reached similar conclusions in his review. We suspect that interactions between environmental variation and fishing pressure will often provide better models (compared with single cause explanations) for the troubles of contemporary Atlantic fisheries.

In theory, there are many reasons why environmental variations - in temperature, salinity, mixing, currents, cloudiness, etc. - should affect fish populations (e.g. Laevastu 1993; Jakobsson et al. 1994). Untangling the causal effects of environment and fishing on marine ecosystems presents a formidable challenge, nevertheless. But whereas environmental variation affects ecosystems in a variety of ways, fishing pressure tends to produce a more systematic pattern of change. This pattern is nowhere more evident than on the recently transformed fishing grounds of the northwest Atlantic.

\section{Changing marine ecosystems}

Cod historically have been the main resource of many Atlantic Arc communities. The scale of fishing was initially small, and confined mostly to inshore waters. Increasing effort and improving technology produced gradual, hard to perceive effects on the resource base - although the size and age of codfish caught declined from one generation to the next, and "codfish as large as a man" moved from common experience into folklore.

During the era after World War II, however, fish populations were pursued with new technology and intensity. Fisheries expanded to all seasons and offshore waters, gaining power to rapidly alter whole ecosystems. Catches peaked at unsustainable levels during the 1960 s or early 70 s, but fell thereafter. By the 1990s, cod and other key demersal (groundfish) resources faced widespread decline or collapse.

As demersal fisheries struggled, fishermen adapted by pursuing alternative species, often invertebrates such as lobster, crab and shrimp (some of which had once been the prey of groundfish). In the 1970 s, shellfish comprised less than $5 \%$ of Newfoundland's landings by weight, and just over $10 \%$ by value. They did not rise much over the next decade, until cod began clearly declining in the late 1980s. But after the 1992 codfish collapse, shellfish landings climbed steeply. By 1995 shellfish accounted for 64\% of Newfoundland's landings by weight, and $89 \%$ by value.

Newfoundland's cod-to-shellfish transition illustrates how a modern fishery can systematically change its ecosystem. The characteristic pattern of changes includes:

a) Reduction in biomass of target species, and of other species taken as bycatch (Gomes et al. 1995) or affected by benthic habitat disruption (Watling \& Norse 1998).

b) Downward shifts in the size distributions of caught fish, due both to the progressive elimination of older age classes, and evolutionary reductions in size-at-age (Haedrich \& Barnes 1997; Haedrich \& Merrett 1998).

c) Reduction in abundance of large predator species, leaving room for expansion by smaller and lower-trophic-level species (Deimling \& Liss 1994).

As a consequence, the mean trophic level shifts closer to primary production, a process termed "fishing down food webs" (Pauly et al. 1998; see also Caddy et al. 1998).

Switching to alternative species drives further changes:

a) Some alternative species are comparatively scarce (e.g. lumpfish), or slow-growing (e.g. Greenland halibut), and hence less able to withstand sustained fishing pressure.

b) Other shorter-lived species including shrimp, herring and capelin, are periodically quite abundant but volatile, subject to great swings in population.

c) Reductions in biomass, size distributions, and 


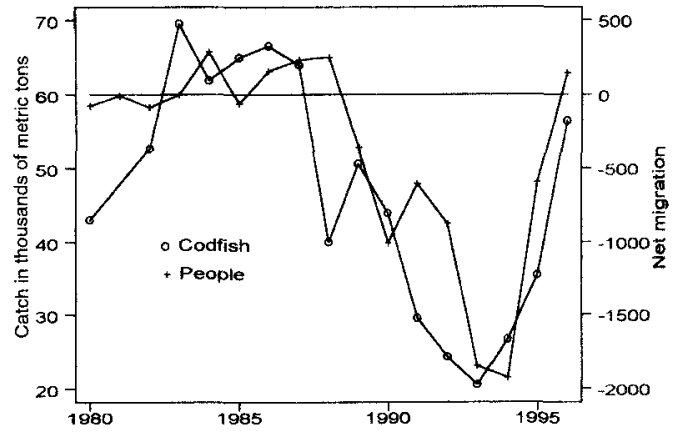

Fig. 1. Faroe Islands total codfish catch and net migration, 1980-1996 (different $y$-axis scales). Data source: Statistics Sweden (1998).

bycatch species next occur in the alternative fishery.

Fisheries' direct ecological effects can have indirect consequences by increasing the vulnerability of fish populations to environmental change. For example, removing most of the large, older individuals could undercut cod populations' natural adaptation to variable environments (Marteinsdottir \& Thorarinsson 1998). Similarly, removal of forage species could make entire ecosystems less resilient.

Substitution of high value shellfish for high value groundfish has been an economically fortunate possibility in many areas, but one with uneven social effects. The people who lose access to one species are not necessarily the same folks who gain access to another. Newfoundland's current crab fishery, for example, supports far fewer fishermen than the former cod fishery although the two are comparable in value. Similarly, Greenland's shrimp fishery depends primarily upon factory trawlers, and secondarily upon mid-sized vessels, but lacks much of the labor-intensive small-boat component that once participated in cod fishing. Geography, marketing, investments and regulations all affect individuals' ability to adapt to a changing ecosystem. Skills also create barriers or opportunities.

\section{Population trends in fishing communities}

Ecological changes, manifested through shifts in the abundance of exploited marine species, have economic and social impacts upon fishing people.
Fishers have responded by increasing the efficiency and range of their fishing efforts. The "alternative species" option has been facilitated by new global markets for types of fish that traditionally were not in demand. Government interventions include restricting catches through quotas or closures; redistribution and exit schemes such as transferable quotas or boat buy-backs; subsidies for fishing sector workers or communities; and investments meant to promote economic diversification. Individual-level adaptations also include new enterprises such as tourism (for example, offering whale-watch cruises), seeking education or training for other jobs, or moving away.

Human adaptive efforts can redirect or disguise the impacts of ecological change, so that some places and people thrive despite seemingly adverse trends in the local resources. Moreover, many fishing-dependent communities have been losing population for years, affected by various factors including the pull of urban life and the push of rural constraints. This makes it more difficult to assess the extent to which demographic shifts reflect ecological change. In some cases, however, details of timing make a good case for ecological influences.

With fish products comprising more than $90 \%$ of their total exports (ca. 1989), the Faroe Islands are among the most fisheries-dependent Atlantic Arc societies. During the 1980 s, their investments in catching and processing capacity led to overfishing of Atlantic cod (Gadus morhua). Landings declined from about 200000 to less than 70000 metric tons between 1987 and 1993. The crisis brought on bankruptcies, deepened the islands' economic dependence on Denmark - and changed demographics. Migration trends closely shadowed the declining codfish landings, with a lag of one or two years (Fig. 1). Net out-migration caused the Faroes population to fall by $9 \%$ from 1989 to 1995 . Young adults were most likely to leave. The 20 to 39 -yearold population actually dropped $18 \%$, while the over-65 population grew by $7 \%$ - making the islands" population on average noticeably older by 1995 than it had been six years earlier.

Another fisheries-dependent society, Greenland counts on fishing for roughly half of its total foreign exchange. Figure 2 contrasts trends in the west Greenland municipalities of Paamiut and Sisimiut. Paamiut had been built up as a cod fishing centre during the years when that resource appeared plentiful along the south-west coast. Overfishing and cooler waters caused cod to 

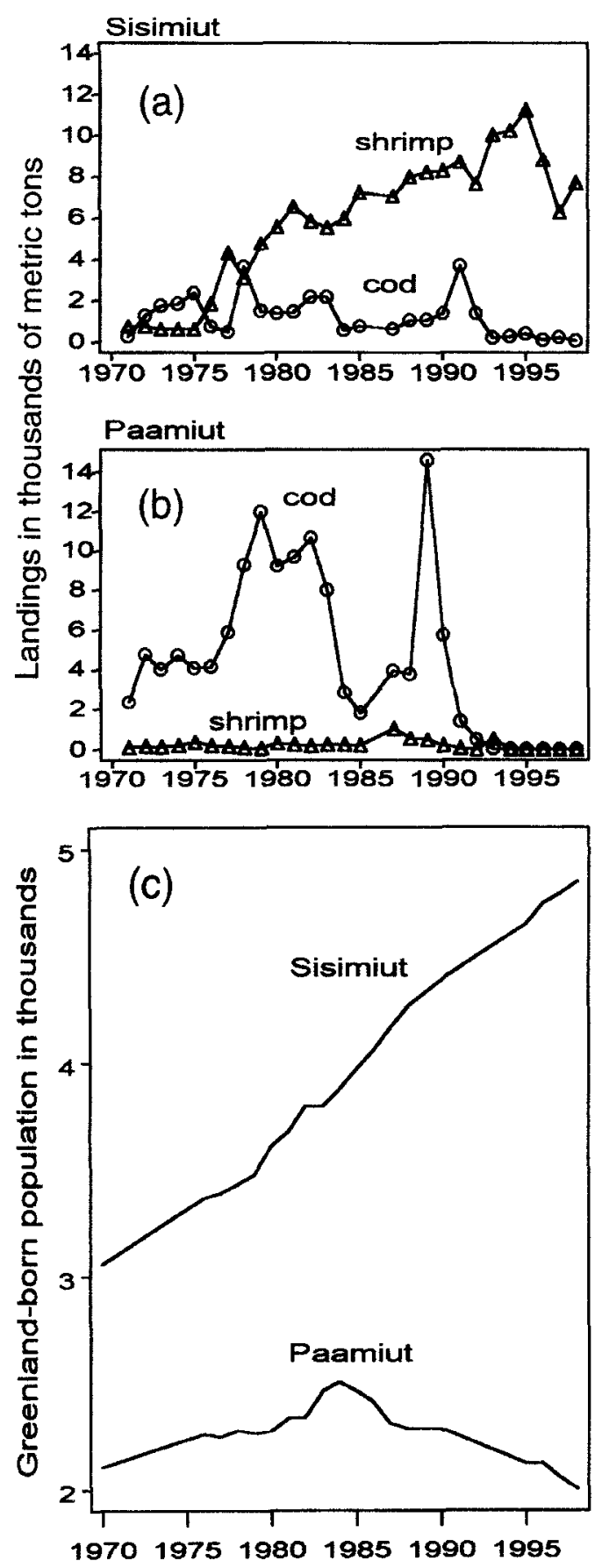

Fig. 2. (a) and (b) Trends in cod and shrimp landings and (c) Greenland-born population of Sisimiut and Paamiut municipalities, 1971-1998. Data sources: Rasmussen \& Hamilton (1999); Statistics Greenland (unpubl.).

decline in the $1980 \mathrm{~s}$, and then to collapse completely in the early 1990s (Rätz 1999), leaving
Paamiut without its main livelihood. While cod fishing was expanding, Paamiut's human population grew too. As the cod decline became evident in the mid-1980s Paamiut's human population began declining as well - by approximately $15 \%$ from 1984 to 1996. Sisimiut, on the other hand, was too far north to have benefitted much from cod fishing but is better positioned for shrimping. As shrimp (Pandalus borealis) abundance and landings increased, Sisimiut itself grew (23\% over 1984-96) to become the second largest municipality in Greenland. In this sense Sisimiut and Paamiut represent a winner and loser, respectively, from the environmental changes that ended west Greenland's cod fishery but replaced it with shrimp (Rasmussen \& Hamilton 1999).

Newfoundland has ten times the population of Greenland or the Faroe Islands, and hundreds more fishing communities. Figure 3 shows changes in Newfoundland population during the transition from expansion to collapse in the cod fishery. Census divisions where at least $5 \%$ of the 1991 workforce was employed in fishing are classed as "fisheries-dependent" for purposes of this analysis. The lowest line in Fig. 3 shows population trends in rural but less fish-dependent parts of the province. These places began losing people during the late 1970s, as new investment (following establishment of a 200 mile economic exclusion zone) was flowing into the increasingly industrialized fishing industry. Population in the most fisheries-dependent regions continued to grow until the mid-1980s, when codfish landings stagnated despite the new investment and technology. The Avalon Peninsula, which includes the capital city of St. John's, grew steadily until 1992, the year of the codfish moratorium. Since then, the province as a whole experienced negative growth.

In Iceland and Norway, declining populations of traditional fishing regions is a topic of concern (Jentoft 1993; Hannesson 1996; Ólafsson 1997). Figure 4 shows Iceland's population from 1971 to 1996. Recent growth has been concentrated in the capital region around Reykjavík (up 24\% from 1984 to 1996). The rest of Iceland, more fisheriesdependent and less economically diverse, stopped growing in the 1980s, and began to contract in the 1990s (falling 2\% from 1984 to 1996). A trend towards population concentration can be seen also within the rural regions themselves. Local hubs may remain stable or grow, while outlying parts of their region decline.

Population decline began earlier for Norwegian 


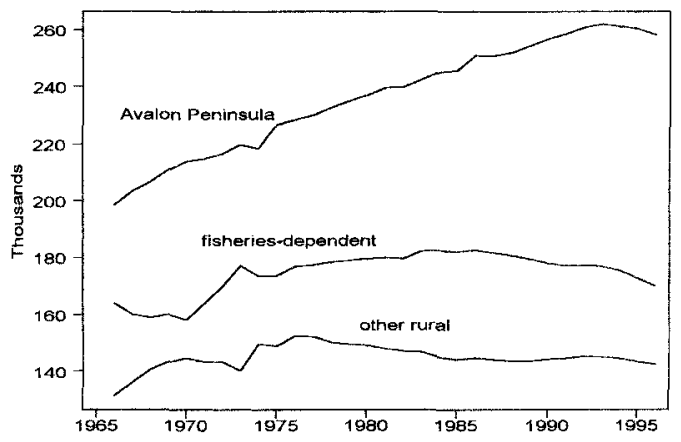

Fig. 3. Population of Newfoundland's capital region, the Avalon Peninsula (top); fisheries dependent rural regions; and other rural regions, 1966-1996. Data source: Economics and Statistics Section, Newfoundland Statistics Agency (unpubl.).

fishing communities. Figure 5 shows that the most fisheries-dependent municipalities (defined here as those with at least $10 \%$ of their 1980 workforce in fishing) stopped growing in the late 1950s, and subsequently began to decline. Figure 5 shows the two populations on different scales, but the fisheries-dependent decline amounted to $18 \%$ over 1960-1991, while other municipalities grew by $21 \%$. As elsewhere, social forces contributed to this flow - better opportunities in cities, higher education levels and more portable skills, new aspirations and gender roles, and the shift from labor-intensive to capital-intensive production, among other things. The population turnaround in this graph coincides, however, with Norway's 1956-1963 herring crisis. A series of subsequent troubles (a second herring collapse in 1968-1972; capelin and cod crises in the late 1980s; partial recovery followed by another codfish decline in the 1990s) have kept pressure on fishing commu-

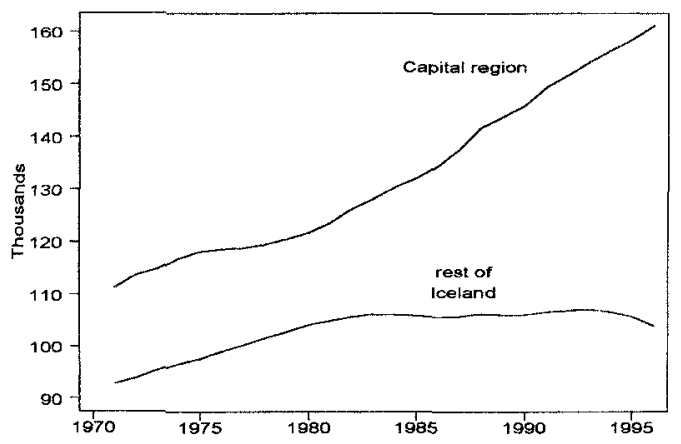

Fig. 4. Population of Iceland's capital region (top) and the rest of Iceland, 1971-1996. Data source: Hagstofa Íslands (1997).

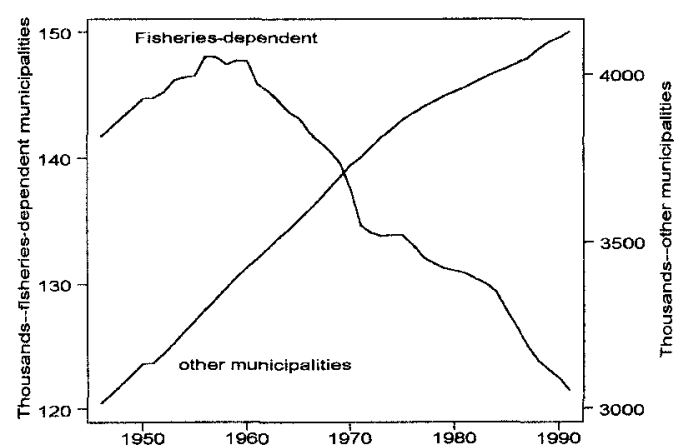

Fig. 5. Populations of fisheries dependent and other municipalities in Norway, 1946-1992 (different $y$-axis scales). Data source: Otterstad (1993).

nities. Hamilton \& Otterstad (1998) examine some demographic changes occurring, as fishing communities struggle to attract young men as workers, or to keep young women from migrating away.

\section{Conclusion}

Some common demographic changes, including a contracting, aging population, can be seen in many Atlantic Arc fishing communities. Social, economic and political factors certainly affect outmigration, but we also see evidence that ecological changes - notably, the widespread declines in demersal fish - play a role. Future adverse changes, including troubles with the alternative species that support newer fisheries, could be expected to accelerate these trends. Such troubles might result from interactions between fishing pressure and environmental variation, including large-scale climatic change.

Theoretical ocean-atmosphere models are continually being refined, in pursuit of better predictions about future climate. Empirical ice and sediment core studies have challenged this modelling effort, by demonstrating that past climate sometimes changed with step-like suddenness, or through flickering transition periods, quite unlike the gradual warming predicted by early computer models. Newer models can more realistically mimic the palaeoclimate record. We suggest that thinking about the human dimensions of climate change could likewise be informed by empirical research on the attitudes, aspirations and behaviour of people in resource-dependent communities. Atlantic fisheries present one instance 
where modern democracies are adapting to largescale environmental changes. Identifying broad similarities in their responses can help to distinguish unique local stories from deeper human ecology patterns, which possibly will characterize the response to future climatic change as well.

Acknowledgements. - The research was supported in part by grants from the Arctic System Science programme of the National Science Foundation, and from Canada's Natural Science and Engineering Research Council.

\section{References}

Broecker, W. S. 1997: Thermohaline circulation, the Achilles heel of our climate system: will man-made $\mathrm{CO}_{2}$ upset the current balance? Science 278, 1582-1588.

Caddy, J. F., Csirke, J., Garcia, S. M. \& Grainger R. J. R. 1998: How pervasive is "fishing down marine food webs"? Science $282,1383 \mathrm{a}$.

Deimling, E. A. \& Liss, W. J. 1994: Fishery development in the eastern North Pacific: a natural-cultural system perspective. Fish. Oceanogr. 3, 60-77.

deYoung, B. \& Rose, G. A. 1993: On recruitment and distribution of Atlantic cod (Gadus morhua) off Newfoundland. Can. J. Fish. Aquat. Sci. 50, 2729-2741.

Gomes, M. C., Haedrich, R. L. \& Villagarcia, M. G. 1995: Spatial and temporal changes in the groundfish assemblages on the northeast Newfoundland/Labrador Shelf, 1978-1991. Fish. Oceanogr. 4, 85-101.

Haedrich, R. L. \& Barnes, S. M. 1997: Changes over time of the size structure in an exploited shelf fish community. Fish. Res. 31, 229-239.

Haedrich, R. L., Fischer, J. \& Chernova, N. V. 1997: Ocean temperatures and demersal fish abundance on the northeast Newfoundland continental shelf. Proceedings, 30th European Marine Biology Symposium. Southampton UK, September 1995. Pp. 211-222.

Haedrich, R.L. \& Merrett, N. R. 1998: Changing size structure in exploited deep-sea fish communities. Poster presented at ICES (International Council for the Exploration of the Seas) Annual Meeting. Council Meeting O:77, Deepwater Fish and Fisheries. Lisbon, September 1998.

Hagstofa Íslands 1997: Landshagir: statistical yearbook of Iceland 1997. Reykjavík: Hagstofa Íslands.

Hamilton, L. C. \& Otterstad, O. 1998: Demographic change and fisheries dependence in the northern Atlantic. Hum. Ecol. Rev. 5(1), 11-24.

Hannessson, R. 1996: Fisheries mismanagement: the case of the North Atlantic Cod. Oxford: Fishing News Books.

Hutchings, J. A. \& Myers, R. A. 1994: What can be learned from the collapse of a renewable resource? Atlantic cod, Gadus morhua, of Newfoundland and Labrador. Can. J. Fish. Aquat. Sci. 51, 2126-2146.

Hutchings, J. A. \& Myers, R. A. 1995: The biological collapse of Atlantic cod off Newfoundland and Labrador: an exploration of historical changes in exploitation, harvesting technology, and management. In R. Arnason \& L. F. Felt (eds.): The North Atlantic fishery: strengths, weaknesses, and challenges. Pp. 37-93. Charlottetown, Prince Edward Island (Canada): Institute of Island Studies.
Jakobsson, J. 1992: Recent variability in the fisheries of the North Atlantic. Int. Counc. Explor. Seas Mar. Sci. Symp. 195 , 291-315.

Jakobsson, J., Astthorsson, O. S., Beverton, R. J. H., Björnsson, B., Daan, N., Frank. K. T., Meincke, J., Rothschild, B., Sundby, S. \& Tilseth, S. (eds.) 1994: Cod and climate change. Proceedings of a symposium held in Revkjavik. Copenhagen: Int. Council for the Exploration of the Sea (ICES).

Jentoft, S. 1993: Dangling lines. The fisheries crisis and the future of coastal communities: the Norwegian experience. St. John's, Newfoundland: Institute of Social and Economic Research.

Laevastu, T. 1993: Marine climate, weather and fisheries. Oxford: Fishing News Books.

Manabe, S. 1995: Simulation of abrupt climate change induced by freshwater input to the North Atlantic Ocean. Nature $378(6553), 165$.

Marteinsdottir, G. \& Thorarinsson, K. 1998: Improving the stock-recruitment relationship in Icelandic cod (Gadus morhua) in including age diversity of spawners. Can. $J$. Fish. Aquat. Sci. 55(6), 1372-1377.

Martin, C. 1995: The collapse of the northern cod stocks: whatever happened to 86/25? Fisheries 20(5), 6-8.

Mayewski, P. A. and 13 others 1994: Changes in atmospheric circulation and ocean ice cover over the North Atlantic during the last 41,000 years. Science $263,1747-1751$.

Ólafsson, S. 1997: Búseta á Íslandi: rannsókn á orsökum biferlaflutninga. (Settlement in Iceland: study of the causes of relocation.) Reykjavík: Byggðastofnun.

Otterstad, O. 1993: Database over norske fiskerisamfunn. (Database on Norwegian fishing communities.) Dragvoll (Norway): Senter for samfunnforskning (SESAM).

Pauly, D., Christensen, V., Dalsgaard, J., Froese, R. \& Torres, F. Jr. 1998: Fishing down marine food webs. Science 279, $860-863$.

Rahmstorf, S. 1995: Bifurcations of the Atlantic thermohaline circulation in response to changes in the hydrological cycle. Nature 378(6553), 145-149.

Rasmussen, R. O. \& Hamilton. L. C. 1999: The development of fisheries in Greenland, with focus on the communities of Paamiut/Frederikshåb and Sisimiut/Holsteinsborg. NAARC working paper 99-01. University of New Hampshire.

Rätz, H.-J. 1999: Structures and changes of the demersal fish assemblage off Greenland and trends in near bottom temperature, 1982-96. North Atl. Fish. Org. Sci. Counc. Stud. 32, 1-15.

Sinclair, A. F. \& S. A. Murawski, S. 1997: Why have groundfish stocks declined? In J. Boreman et al. (eds.): Northwest Atlantic groundfish: perspectives on a fishery collapse. Pp. 71-93. Bethesda MD: American Fisheries Society.

Statistics Sweden 1998: Statistics without borders: Nordisk statistikk på cd-rom. Stockholm: Statistics Sweden, Unit for Dissemination.

Vilhjálmasson, H. 1997: Climatic variations and some examples of their effects on the marine ecology of Icelandic and Greenlandic waters, in particular during the present century. J. Mar. Res. Inst., Reykjavik 15(1), 9-29.

Watling, L. \& Norse, E. A. 1998: Disturbance of the seabed by mobile fishing gear: A comparison to forest clearcutting. Conserv. Biol. 12(6), 1180-1197.

Weaver. A. J. 1995: Driving the ocean conveyor. Nature 378(6553), 135-136. 